\title{
Elevated serum procollagen type III peptide in splanchnic and peripheral circulation of patients with inflammatory bowel disease submitted to surgery
}

\author{
Matilde De Simone ${ }^{1}$, Ugo Cioffi ${ }^{1}$, Ettore Contessini-Avesani ${ }^{1}$, \\ Barbara Oreggia1, Roberta Paliotti, Alberto Pierini², Gianni Bolla², \\ Elide Oggiano ${ }^{2}$, Stefano Ferrero ${ }^{3}$, Fabio Magrini ${ }^{2}$ and Michele M Ciulla*
}

\begin{abstract}
Address: ${ }^{1}$ Department of Surgery, Ospedale Maggiore di Milano, IRCCS, University of Milan, V. F. Sforza, 35 - 20122, Milan, Italy, ${ }^{2}$ Istituto di Medicina Cardiovascolare, Centro Interuniversitario di Fisiologia Clinica e Ipertensione, Ospedale Maggiore di Milano, IRCCS, University of Milan, V. F. Sforza, 35 - 20122, Milan, Italy and ${ }^{3}$ II Cattedra di Anatomia Patologica, Dipartimento di Medicina Chirurgia e Odontoiatria, A.O. San Paolo and Ospedale Maggiore di Milano, IRCCS, University of Milan, V. A. di Rudinì - 20100, Milan, Italy

Email: Matilde De Simone - matilde.desimone@unimi.it; Ugo Cioffi - ugo.cioffi@unimi.it; Ettore ContessiniAvesani - ettore.contessini@unimi.it; Barbara Oreggia - ettore.contessini@unimi.it; Roberta Paliotti - roberta.paliotti@unimi.it; Alberto Pierini - img.lab@mailserver.unimi.it; Gianni Bolla - img.lab@mailserver.unimi.it; Elide Oggiano - img.lab@mailserver.unimi.it; Stefano Ferrero - stefano.ferrero@unimi.it; Fabio Magrini - fabio.magrini@unimi.it; Michele M Ciulla* - michele.ciulla@unimi.it

* Corresponding author
\end{abstract}

Published: 04 November 2004

BMC Gastroenterology 2004, 4:29 doi:10.1 186/1471-230X-4-29

This article is available from: http://www.biomedcentral.com/I47I-230X/4/29

(c) 2004 De Simone et al; licensee BioMed Central Ltd.

This is an Open Access article distributed under the terms of the Creative Commons Attribution License (http://creativecommons.org/licenses/by/2.0), which permits unrestricted use, distribution, and reproduction in any medium, provided the original work is properly cited.

\begin{abstract}
Background: In the hypothesis that the increased collagen metabolism in the intestinal wall of patients affected by inflammatory bowel disease (IBD) is reflected in the systemic circulation, we aimed the study to evaluate serum level of procollagen III peptide (PIIIP) in peripheral and splanchnic circulation by a commercial radioimmunoassay of patients with different histories of disease.
\end{abstract}

Methods: Twenty-seven patients, 17 with Crohn and 10 with ulcerative colitis submitted to surgery were studied. Blood samples were obtained before surgery from a peripheral vein and during surgery from the mesenteric vein draining the affected intestinal segment. Fifteen healthy age and sex matched subjects were studied to determine normal range for peripheral PIIIP.

Results: In IBD patients peripheral PIIIP level was significantly higher if compared with controls $(5.0 \pm \mathrm{I} .9$ vs $2.7 \pm 0.7 \mu \mathrm{g} / \mathrm{l} ; \mathrm{p}=0.000 \mathrm{I})$; splanchnic PIIIP level was $5.5 \pm 2.6 \mu \mathrm{g} / \mathrm{l}$ showing a positive gradient between splanchnic and peripheral concentrations of PIIIP. No significant differences between groups nor correlations with patients' age and duration of disease were found.

Conclusions: We provide evidence that the increased local collagen metabolism in active IBD is reflected also in the systemic circulation irrespective of the history of the disease, suggesting that PIIIP should be considered more appropiately as a marker of the activity phases of IBD.

\section{Background}

Crohn's disease (CD) and Ulcerative Colitis (UC) are chronic inflammatory bowel diseases (IBD) of unknown origin of adolescent and young adulthood [1] where 
genetic polimorphisms [2,3], abnormal inflammation pathways activation [4], and environmental influences [5] seem to concur at different levels in the pathogenesis and the progression of IBD. These pathologic conditions are characterized by focal or diffuse inflammation of the alimentary tract, mucosal damage and epithelial destruction. IBD may be associated with an inability of the intestinal mucosa to protect itself from luminal challenges and inappropriate repair following intestinal injury [6-10]. CD differs from UC by the transmural granulomatous inflammation generally leading to fibrosis, strictures and fistulas [11].

Current opinions suggest that an increased synthesis of collagen type I, III, and V may play an important role in the pathophysiological mechanism leading to intestinal fibrosis [12-15]. An increased synthesis of collagen, namely an increased of procollagen type III, is well documented in fibrotic processes involving other organs such as liver, pancreas, and lung [16-18].

However, not all authors are in agreement regarding the increased serum levels of the aminoterminal propeptide (PIIIP) of collagen in peripheral and splanchnic circulation of patients with active IBD $[13,14]$. Below we present the results on the serum level of PIIIP in splanchnic and peripheral circulation in patients with active IBD submitted to surgery.

\section{Methods}

Twenty-seven patients affected by active IBD, 17 with CD (age $40.2 \pm 13.1$, yrs from diagnosis $9.2 \pm 5.5$ ), and 10 with UC (age $50.3 \pm 15.6$, yrs from diagnosis $9.8 \pm 7.4$ ) submitted to surgery, were enrolled in the study in a double blind fashion. The protocol was approved by local Ethical Committee and informed consent was obtained from all participants to the study. Three patients had CD in small bowel only, two in large bowel only, 12 had ileocolonic disease. Disease activity was assessed according to the Crohn's Disease Activity Index (CDAI) [19] and the Truelove-Witts index (TWI) [20] for CD and UC, respectively. According to CDAI, 2 patients were subclassified as having a moderate form of disease while 15 patients were subclassified as having a severe form of disease. According to TWI, 3 patients were classified as having moderate form of disease, 4 a mild form, and 3 a severe form of disease.

Patients affected by CD were operated on for recurrent obstruction, whereas patients with UC were submitted to surgery because of refractory to medical therapy.

The clinical diagnosis was confirmed by histology (Fig. 1); all cases under study fulfilled the histological criteria as follows:
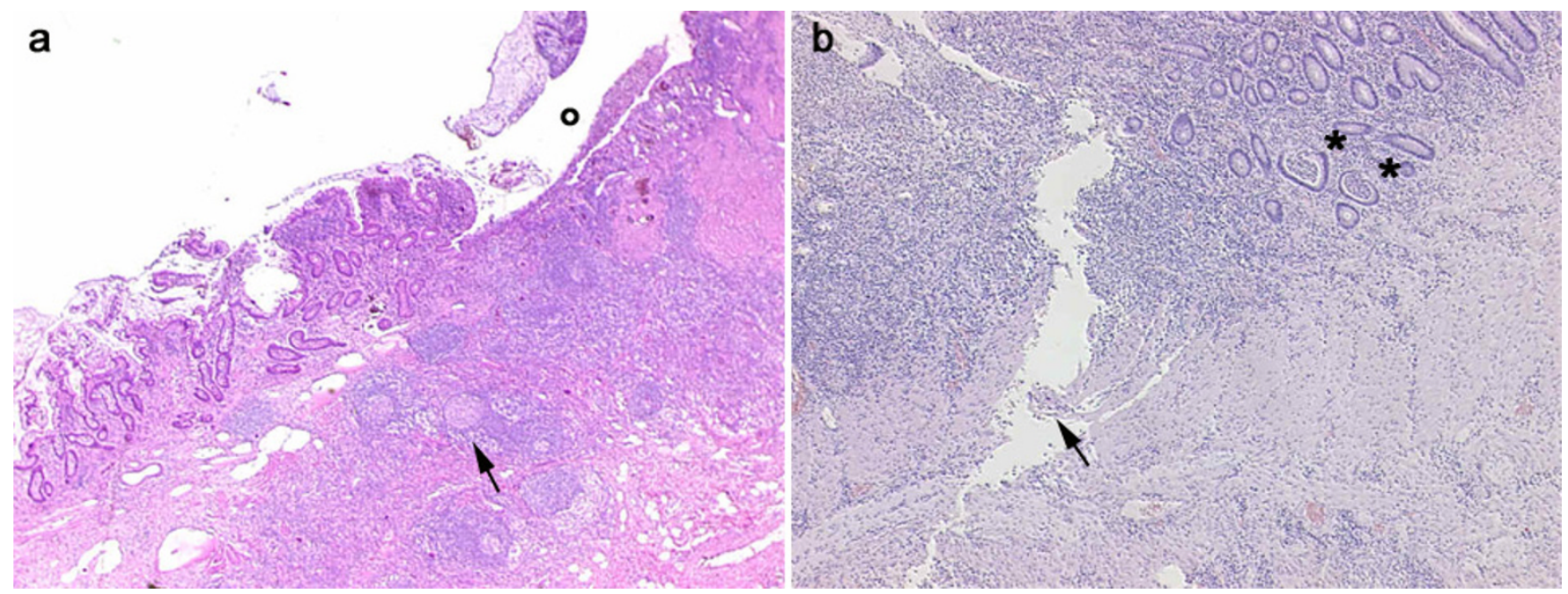

\section{Figure I}

Histological images obtained from two IBD patients enrolled in the study affected by CD (panel a) and UC (panel b) with I2.0 and $10.3 \mu \mathrm{g} / \mathrm{l}$ splanchnic levels of PIIIP, respectively. Panel $a, C D$ : in the transmural section is clearly evident an ulceration (o) in the mucosa and submucosa with diffuse inflammatory infiltrations, pseudo-follicle nodules (arrow), and fibrosis of the intestinal wall. Panel b, UC: the inflammatory infiltration is more evident in the mucosa and submucosa with criptic abscesses (asterisks). A serpiginous linear ulcer is evident (arrow). 
Table I: Clinical aspects of the studied patients

\begin{tabular}{|c|c|c|c|c|c|}
\hline Disease & $\begin{array}{c}\mathbf{N}^{\circ} \text { of } \\
\text { patients }\end{array}$ & Age & Sex & $\begin{array}{c}\text { Years from } \\
\text { diagnosis }\end{array}$ & $\begin{array}{c}\text { Activity } \\
\text { index }\end{array}$ \\
\hline \multirow[t]{18}{*}{ Crohn } & & & & & CDAI \\
\hline & I & 34 & $\mathrm{~F}$ & 12 & Severe \\
\hline & 2 & 35 & $M$ & 8 & Moderate \\
\hline & 3 & 38 & $M$ & 15 & Severe \\
\hline & 4 & 32 & $\mathrm{~F}$ & 8 & Severe \\
\hline & 5 & 43 & $\mathrm{~F}$ & 14 & Severe \\
\hline & 6 & 35 & $M$ & 8 & Severe \\
\hline & 7 & 58 & $M$ & 5 & Severe \\
\hline & 8 & 61 & $\mathrm{~F}$ & 7 & Severe \\
\hline & 9 & 33 & $M$ & 8 & Severe \\
\hline & 10 & 35 & $\mathrm{~F}$ & 19 & Severe \\
\hline & 11 & 21 & $\mathrm{~F}$ & 4 & Severe \\
\hline & 12 & 72 & $\mathrm{~F}$ & I & Severe \\
\hline & 13 & 36 & $M$ & 15 & Moderate \\
\hline & 14 & 42 & $M$ & 7 & Severe \\
\hline & 15 & 25 & $\mathrm{~F}$ & 6 & Severe \\
\hline & 16 & 51 & $\mathrm{~F}$ & 18 & Severe \\
\hline & 17 & 34 & $M$ & I & Severe \\
\hline \multirow{11}{*}{$\begin{array}{l}\text { Ulcerative } \\
\text { colitis }\end{array}$} & & & & & TWI \\
\hline & I & 68 & $\mathrm{~F}$ & 15 & Severe \\
\hline & 2 & 70 & $\mathrm{~F}$ & I & Moderate \\
\hline & 3 & 21 & $\mathrm{~F}$ & 3 & Mild \\
\hline & 4 & 54 & $\mathrm{~F}$ & 20 & Moderate \\
\hline & 5 & 52 & $M$ & 20 & Mild \\
\hline & 6 & 38 & $M$ & 4 & Moderate \\
\hline & 7 & 64 & $M$ & 6 & Mild \\
\hline & 8 & 38 & $\mathrm{~F}$ & 16 & Severe \\
\hline & 9 & 41 & $\mathrm{~F}$ & 3 & Severe \\
\hline & 10 & 57 & $M$ & 10 & Mild \\
\hline
\end{tabular}

CDAl: Crohn's Disease Activity Index; TWI: truelove-Witts index.

- for CD: deep ulcers, marked proliferation of small lymphoid nodules involving all layers of intestinal wall sometime with sarcoid-type granulomas and serosal inflammation;

- for UC: mucosal erosions and superficial ulcerations usually limited to the upper submucosa with cryptic abscesses and glandular destruction.

The clinical profile of the studied patients is reported (Table 1). Two patients did not receive any medication, whereas other patients received two or three drugs for the treatment of IBD. Table 2 shows the treatment protocol for all the studied patients. A control group of 15 healthy age and gender matched subjects was also studied to determine normal range for peripheral PIIIP.

\section{Collagen metabolism (PIIIP)}

Different kinds of collagen have been identified in humans. All of them derive from longer precursor mole-
Table 2: Frequency distribution for therapy

\begin{tabular}{lccc}
\hline Therapy & $\begin{array}{c}\mathbf{N}^{\circ} \text { of } \\
\text { patients }\end{array}$ & $\begin{array}{c}\text { Crohn } \\
\text { Ulcerative } \\
\text { colitis }\end{array}$ \\
\hline No & 2 & 1 & 1 \\
Aminosalicydic acid & 9 & 8 & 1 \\
Cortisone & 2 & 2 & 0 \\
Aminosalicydic acid + Cortisone & 14 & 6 & 8 \\
Total & 27 & 17 & 10 \\
\hline
\end{tabular}

cules (procollagens). They are synthesized intracellularly and secreted in extracellular space where they are cleaved by aminoproteases [21-23]. Among the different kinds of precursors, type III is one of the most abundant interstitial procollagens. Since its aminoterminal propeptide, PIIIP, is formed in equimolar proportions to collagen, serum measurements of this fragment can provide an index of collagen synthesis [23]. The blood samples (two, 5-ml each) for PIIIP measurements were taken from the median cubital vein (p-PIIIP) before surgery after an overnight fast, during surgery from a mesenteric vein (s-PIIIP) draining the intestinal segment chosen for resection by the surgeon. Serum levels of PIIIP were assessed by commercial radioimmunoassay (Orion Diagnostics, Finland). The intra-assay and inter-assay variation were respectively $4 \%$ and $4.3 \%$, mean $2.6 \mu \mathrm{g} / \mathrm{l}$. Normal ranges of peripheral PIIIP concentrations assessed in the control group were $2.7 \pm 0.7 \mu \mathrm{g} / \mathrm{l}$.

\section{Statistical analysis}

Data were analyzed using a computer statistical software (SPSS-Rel 10; SPSS Inc., Chicago, Ill). All the quantitative variables were tested for Gaussian distribution with the Kolmogorov-Smirnov test. All that followed this distribution were presented as mean \pm standard deviation.

Differences at baseline in collagen parameters between IBD patients and controls were tested for significance using the analysis of variance with the Bonferroni correction. The relation between collagen parameters and the estimated duration of the disease and indices of disease were tested with regression analysis. In all cases, a p value less than 0.05 was considered significant.

\section{Results}

\section{Peripheral PIIIP assay}

At baseline, before surgery, serum p-PIIIP in IBD patients were significantly higher if compared with healthy controls $(5.0 \pm 1.9$ vs $2.7 \pm 0.7 \mu \mathrm{g} / \mathrm{l}$, respectively; $\mathrm{p}=0.0001)$ (fig 2a). No significant differences were found when comparing CD and UC subgroups $(5.0 \pm 1.6$ vs $4.9 \pm 2.4 \mu \mathrm{g} / \mathrm{l}$, respectively; $\mathrm{p}=\mathrm{ns}$ ) (fig $2 \mathrm{~b}$ ). 

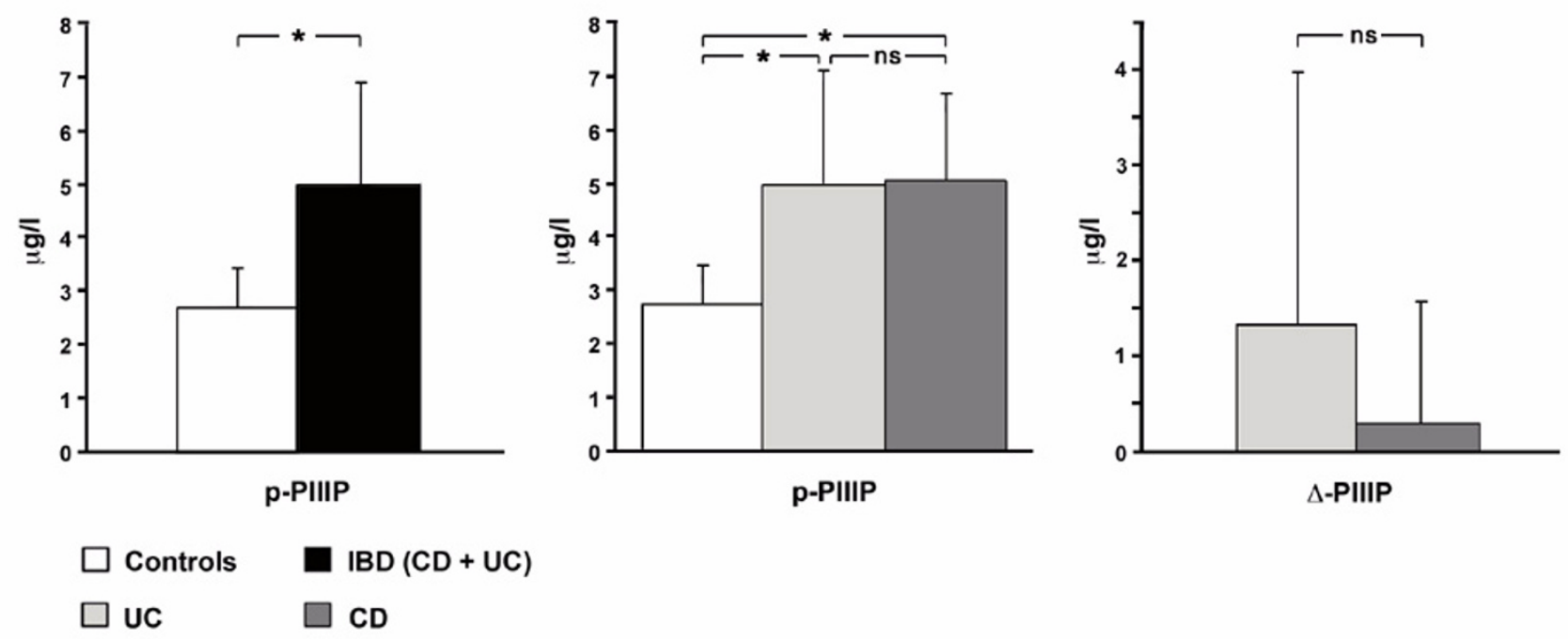

Figure 2

Panel a: Differences in baseline p-PIIIP values in Controls and IBD patients. Panel b: No significant differences in p-PIIIP values between CD and UC subgroups. Panel $c$ : Differences between splancnic and periferic values of PIIIP, without significant differences in CD and UC sbgroups. P-PIIIP: periferic (median cubital vein) PIIIP; s-PIIIP: splancnic (mesenteric vein) PIIIP; $\Delta$-PIIIP: differences between s- and P-PIIIP in IBD patients; IBD: inflammatory bowel diseases; CD: Crohn's Disease; UC: ulcerative colitis;

\section{Splanchnic PIIIP assay}

During surgery, serum s-PIIIP in IBD patients was $5.5 \pm$ $2.6 \mu \mathrm{g} / \mathrm{l}$. No significant differences were found when comparing CD and UC subgroups $(5.4 \pm 2.3$ vs $5.7 \pm 3.1 \mu \mathrm{g} / \mathrm{l}$, respectively; $\mathrm{p}=\mathrm{ns}$ ). A positive gradient was found in IBD patients between splanchnic and peripheral serum concentrations of PIIIP $(0.7 \pm 1.9 \mu \mathrm{g} / \mathrm{l})$. This gradient was confirmed when separately considering each disease, without significant differences between the two subgroups (CD $0.3 \pm 1.3$ vs UC $1.3 \pm 2.6 \mu \mathrm{g} / \mathrm{l} ; \mathrm{p}=\mathrm{ns}$ ) (fig $2 \mathrm{c}$ ).

\section{Other variables and PIIIP levels}

No significant correlation was found between peripheral and splanchnic levels of PIIIP and the age of the patients and the estimated duration of the disease. Regarding the activity indices, the number of patients belonging to each class was not enough to perform a statistical analysis. Notwithstanding, for the TWI in UC patients a significant difference in PIIIP levels was found between mild and severe form of the disease (Table 3). Finally, no significant differences were found in PIIIP levels between patients treated with glucocorticoids compared with patients not receiving this treatment.
Table 3: Baseline p-PIIIP levels in UC patients

\begin{tabular}{ll}
\hline TWI Activity Index & \multicolumn{1}{c}{ Mean \pm SD } \\
\hline Mild & $7.05 \pm 2.25$ \\
Moderate & $3.9 \pm 1.11$ \\
Severe & $3.13 \pm 1.57^{*}$ \\
\hline
\end{tabular}

$*_{p}=0.02$ vs mild

\section{Discussion}

CD and UC are chronic pathologies characterized by an early onset followed by sporadic episodes of acute symptoms during lifetime, debilitating the affected patients to perform their daily functions [24]. Until now controversial theories exist about the synthesis and degradation of PIIIP, its level on systemic circulation, and its deposition far for main target organ $[12,13,15,25]$.

In the present study we have found that intestinal collagen metabolism in IBD patients was increased and that it is reflected in local and systemic circulation. Differently from some experiences $[12,13]$, we have found that serum PIIIP levels in IBD patients was significantly higher if 
compared with healthy subjects. No significant differences were found in peripheral and splanchnic circulation between patients affected by UC and CD. We also found a positive gradient between serum s-PIIIP and p-PIIIP levels in IBD patients. This gradient was confirmed when considering serum s-PIIIP and p-PIIIP in UC and CD separately, even if the differences between the two subgroups were not statistically significant. In our experience no significant differences were found when considering the age of the patients, the duration of the disease, and the activity indices. This fact implies that serum PIIIP should not be considered a long-term marker of the disease, probably reflecting the short-term fluctuation in the activity phases of the remodeling processes.

When comparing the mild with the severe form of the disease, a significant difference in PIIIP levels was found only in patients affected by UC. This data will probably be confirmed when the number of patients enrolled in each disease-related activity categories is extended as presently in our series the majority of the patients were classified as severe.

The effect of glucocorticoids on collagen synthesis, collagenase, and collagen degradation has not yet fully been clarified [25]. In our study the cortisone therapy did not have influence on the PIIIP levels, but the number of patients was too small and it was not possible to speculate on this regard.

\section{Conclusions}

In conclusion we provide evidence that collagen metabolism in IBD is reflected in the systemic and local circulation, without any differences between UC and CD, irrespective of the age of the patients and the duration of the disease. Therefore, this marker may give further information on the activity phases rather than on the entire history of the disease. Further data on the possible use of PIIIP as useful marker of choice for surgical option are attended from the follow-up at 6 and 12 months, which is still on-going [26].

\author{
List of abbreviations \\ Inflammatory bowel diseases $=$ IBD \\ Procollagen III propeptide $=$ PIIIP \\ Peripheral Procollagen III propeptide $=$ p-PIIIP \\ Splanchnic Procollagen III propeptide = s-PIIIP \\ Crohn's disease $=\mathrm{CD}$ \\ Ulcerative Colitis $=\mathrm{UC}$
}

Crohn's Disease Activity Index = CDAI

Truelove-Witts index $=$ TWI

\section{Competing interests}

The author(s) declare that they have no competing interests.

\section{Authors' contributions}

UC conception and design, interpretation of data, drafting the article

MDS conception and design, interpretation of data, drafting the article

ECA performed surgical operations, critical revision of the article, final approval of the version

BO patients' enrollement, blood samples collection

RP statistical analysis, interpretation of data, drafting the article

AP echocardiographic studies

GB radioimmunoassays

EO radioimmunoassays

SF histological examinations

FM interpretation of data, critical revision of the article, final approval of the version

MMC conception and design, interpretation of data, drafting the article

All Authors read and approved the final manuscript.

\section{References}

I. Fiocchi C: Inflammatory bowel disease: etiology and pathogenesis. Gastroenterology 1998, I I 5: 182-205.

2. Zheng CQ, Hu GZ, Zeng ZS, Lin LJ, Gu GG: Progress in searching for susceptibility gene for inflammatory bowel disease by positional cloning. World J Gastroenterol 2003, 9: 1646-1656. Review

3. Tamboli CP, Cortot A, Colombel JF: What are the major arguments in favour of the genetic susceptibility for inflammatory bowel disease? Eur J Gastroenterol Hepatol 2003, 15:587-592.

4. Devani M, Cugno M, Vecchi M, Ferrero S, Di Berardino F, Avesani EC, de Franchis R, Colman RW: Kallikrein-kinin system activation in Crohn's disease: differences in intestinal and systemic markers. Am J Gastroenterol 2002, 97:2026-2032.

5. Krishnan A, Korzenik JR: Inflammatory bowel disease and environmental influences. Gastroenterol Clin North Am 2002, 3 I :2 I-39.

6. Ciulla M, Cioffi U, De Simone M, Contessini-Avesani E: TGF-beta I and collagen methabolism in IBD patients. Med Sci Monit 2002, 8:LE55-56.

7. Hendrickson BA, Gokhale R, Cho JH: Clinical aspects and pathophysiology of inflammatory bowel disease. Clin Microbiol Rev 2002, 15:79-94. 
8. Chutkan RK: Inflammatory bowel disease. Prim Care 200I, 28:539-556.

9. Harper PC, McAuliffe TL, Beeken WL: Crohn's disease in the elderly. A statistical comparison with younger patients matched for sex and duration of disease. Arch Intern Med 1986, 146:753-755.

10. Oliva-Hemker M, Fiocchi C: Etiopathogenesis of inflammatory bowel disease: the importance of the pediatric perspective. Inflamm Bowel Dis 2002, 8: I I2-I28.

II. Pucilowska JB, McNaughton KK, Mohapatra NK, Hoyt EC, Zimmermann EM, Balfour Sartor R, Kay Lund P: IGF-I and procollagen a I (I) are coexpressed in a subset of mesenchymal cells in active Crohn's disease. Am J Physiol Gastrointest Liver Physiol 2000, 279:GI307-I322.

12. Kjeldsen J, Schaffalitzky de Muckadell OB, Junker P: Seromarkers of collagen I and III metabolism in active Crohn's disease. Relation to disease activity and response to therapy. Gut 1995, 37:805-8I0

13. Kjeldsen J, Rasmussen M, Schaffalitzky de Muckadell OB, Kronborg O, Junker P: Collagen metabolites in the peripheral and splanchnic circulation of patients with Crohn disease. Scand J Gastroenterol 200I, 36: I 193-II97.

14. Silvennoinen J, Risteli L, Kartunen T, Risteli J: Increased degradation of type I collagen in patients with inflammatory bowel disease. Gut 1996, 38:223-228.

15. Stallmach A, Schuppan D, Riese HH, Matthes H, Riecken EO: Increased collagen type III synthesis by fibroblasts isolated from strictures of patients with Crohn's disease. Gastroenterology 1992, 102:1920-1929.

16. Hahn EG, Schuppan D: Ethanol and fibrinogenesis in the liver. In In Alcohol-related disease in gastroenterology Edited by: Seitz HK, Kommerell B. Berlin: Springer-Verlag; 1985:124-153.

17. Uscanga L, Kennedy RH, Choux R, Drugmont M, Grimand JA, Sarles $\mathrm{H}$ : Sequential connective tissue matrix changes in experimental acute pancreatitis. An immunohistochemical and biochemical assessment in the rat. Int J Pancreatol 1987, 2:33-45.

18. Cantin AM, Boileau R, Begin R: Increased procollagen III aminoterminal peptide related antigens and fibroblastic growth signals in the lungs of patients with idiopathic pulmonary fibrosis. Am Rev Respir Dis 1988, 137:572-578.

19. Best WR, Becktel JM, Singleton JW, Kern F: Development of a Crohn's disease activity index. Gastroenterology 1976, 70:439-444.

20. Truelove SC, Witts LJ: Cortisone in ulcerative colitis: final report of a therapeutic trial. Br Med J 1955, 4947: I04I- I048.

21. Prockop DJ, Kivirikko KI, Tuderman L, Guzman NA: The biosynthesis of collagen and its disorders. N Engl J Med 1979, 30I: I3-23.

22. Querejeta R, Varo N, Lopez B, Larmanet M, Artinano E, Etayo JC, Martinez JL, Gutierrez-Stampa M, Emparanza JI, Gil MJ, Monreal I, Mindan JP, Diez J: Serum carboxi-terminal propeptide of procollagen type $I$ is a marker of myocardial fibrosis in hypertensive heart disease. Circulation 2000, I01:1729-1735.

23. Fessler JH, Fessler LI: Biosynthesis of procollagen. Annu Rev Biochem 1978, 47:129-162.

24. Longobardi $\mathrm{T}$, Jacobs $\mathrm{P}$, Bernstein $\mathrm{CN}$ : Work losses related to inflammatory bowel disease in the United States: Results from the National Health Interview Survey. Am J Gastroenterol 2003, 98: 1064-1072.

25. Babic Z, Jagic V, Petrovic Z, Bilic A, Dinko K, Kubat G, Troskot R, Vukelic M: Elevated serum values of procollagen III peptide (PIIIP) in patients with ulcerative colitis who will develop pseudopolyps. World J Gastroenterol 2003, 9:619-621.

26. Cioffi U, Ciulla MM, De Simone M, Paliotti R, Pierini A, Magrini F, Botti $F$, Contessini-Avesani E: Effects of chronic inflammatory bowel diseases on left ventricular structure and function: a study protocol. BMC Public Health 2002, 2: 19.

\section{Pre-publication history}

The pre-publication history for this paper can be accessed here:

\section{http://www.biomedcentral.com/1471-230X/4/29/pre} pub
Publish with Biomed Central and every scientist can read your work free of charge

"BioMed Central will be the most significant development for disseminating the results of biomedical research in our lifetime. "

Sir Paul Nurse, Cancer Research UK

Your research papers will be:

- available free of charge to the entire biomedical community

- peer reviewed and published immediately upon acceptance

- cited in PubMed and archived on PubMed Central

- yours - you keep the copyright
Biomedcentral 